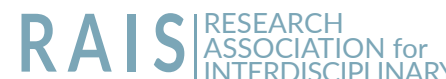 OCTOBER 2017 STUUDIES
}

\section{Juxtaposition of Eastern Management Styles and practices with Modern Management System and Concepts}

\author{
Nidhi Kaushal \\ Research Scholar Department of Applied Science \\ and Eng.at I.I.T. Roorkee, India \\ nidhi.k3333@gmail.com \\ Sanjit Mishra \\ $\mathrm{PhD}$, Associate Professor Department of Applied Science \\ and Eng.at I.I.T. Roorkee, India \\ sanjitmishra2001@yahoo.com
}

\begin{abstract}
This paper presents an analysis of the Indian management concepts in view of the changing world order while establishing their inter relatedness with the theories and practices developed in the West. Being followed by the leaders and entrepreneurs of the country right since the Vedic ages, the ancient Indians had developed their own management systems with the help of which they successfully carried out their business affairs. It is the hypothesis that the practices thus cultured and the concepts thus evolved, are relevant across the boundaries of time and space, and shall be immensely helpful for the organizations of the west as well. In this paper they have examined the organizational and other managerial skills in the works of spiritual- social reformers and other political leaders from India. The Indian perspective on management is based on the Purushartha (a key concept and denotes the four proper aims of a human life). It was the base model of management in ancient time which has been followed by management thinkers and leaders of India.

KEY WORDS: Culture, Entrepreneur, Ethics, Globalization, Leadership, Management, Organization.
\end{abstract}




\section{Introduction}

According to Ravichandran (2009),'Management learning in India is predominately a derivative of western management thought and practice. Occasionally, management schools draw some inferences from Indian epics, shastras and practices. It may be worthwhile to notice that management itself as a discipline has evolved from fundamental disciplines of philosophy, psychology, economics, accounting, computer science, mathematics, statistics and industrial engineering. The modern management education in India emphasizes on performance and very little on purpose. It equips the young men and women to generate wealth and does not provide them the capacity to enjoy and share this wealth. It projects the use of the information technology as an enabler to improve efficiency but not as a supporting tool in resolving large complex social issues. It motivates individuals to accomplish their objectives with or without regard to means. As a rule, management education has completely detached itself from the under managed sectors. A handful of management institutions in this country are trying to realign the management education by using a multidimensional approach. The first dimension of this would focus on the individuals. The second dimension (of this education) would focus on the standard tools and techniques of management education. The third dimension would connect the individual to the society by compassion, entrepreneurship and social sensitivity'.

According to Devarajan (2013), 'Art and science of management can be related to Hindu mythology - the connectivity between "Belief" and "Business" and mythology is as much objective and pragmatic as the principles in management. Belief is the basis from which "sprouts every human enterprise, and every culture. But every belief is irrational and hence, a myth. Therefore, the study of stories, symbols, and rituals to decode the beliefs that they communicate is called mythology." We used the term Business Sutra in Hindu mythology. The word Sutra means an aphorism - a terse statement."The leader is a heroic individual described by Kishore (2010) of some sort who summons his followers to accomplish great things. There is a tendency to glorify leadership as an achievement or a sort of reward for one's performance in a specific sphere of life. In other words, an individual with a greater degree of selflessness is the ideal candidate to be a leader of other human beings. A leader whose foundation is the idea of selflessness manifests this in many forms in his relationship with followers like

1. Freedom - The first ideal of such an enlightened leader would be 'freedom'. A selfless leader would allow other individuals to operate with a high degree of freedom while providing an outline of what needs to be accomplished. A selfless 
leader, on the other hand, will demonstrate a lesser tendency to control simply due to the absence of any desire in him to stamp his individual personality on everything that his team produces.

2. Follower evolution centrality - A selfless leader would be constantly conscious of the specific evolutionary state of his follower, and would constantly try to raise him to higher levels of selflessness.'

\subsection{The outlook of management in Indian Literature}

According to Chatterji (2016), 'Since ancient times in India, the Purusharthas has served as the road map for leading a successful and a peaceful life. They form the primary aims of the human life. The four guiding principles that are together known as Purusharthas are Dharma, Arhta, Kama and Moksha. The Purusharthas assume different meaning in different context, are non-translatable and subsume several words in one. One should pursue the right desires and perform the right actions which come under the framework of dharma. So moksha provides the vision for one's life and Dharma provides the precise guidelines for one's thoughts and actions and hence Moksha and Dharma are the important principles for leadership. The desire (Kama) to attain wealth and material wellbeing (Artha) is best when pursued in the framework of Dharma and Moksha.

Purusharthas defined in terms of ethical leadership is given below:

Dharma $=$ Ethics

Artha $=$ Profit $/$ Material well being

Kama $=$ Desire/ Ambition

Moksha $=$ Inclusivity $/$ Freedom from Limited identities

A proper balance among these Purushathas is required for successful leadership. So ethical leadership not only includes adhering to moral values but also develop a sense of inclusivity towards society and the environment. While ethics and moral values may bring objectivity to leadership, Moksha defined in this context, brings in the missing subjective components like happiness, contentment, agreeableness, and inclusivity, which are vital to ethical leadership.

Sthairym is the quality that indicates resoluteness or perseverance. Swami Dayand Saraswati in his book value of value says, "When it comes to applying effort towards a goal, most of us find ourselves to be 'aarambha surah' that is 'heroes in the beginning. We are the lions at first but then enthusiasm wanes." It is in fact natural for a fledging 
manager to start off a mental bearing oriented to act ethically. Sthairym is the quality that can sustain and nurture this very orientation there by one in to an ethical leader.'

\subsection{Application of the Purushartbas}

According to Chatterji (2016),'Application of the Purusharthas means having dharma as the foundation for the pursuit of the Artha and Kama while keeping Moksha as the vision. In other words ones's thoughts and actions should have ethics and responsibility as the foundation and not just materialistic goals. In an organizational setting, the way to accelerate it is through the iterative process of Sarvana (listening), Manana (Contemplation) and Nidhidhyasna (integration and practice). Sarvana can happen through the education and training process wherein the individual get systematically exposed to the literature expounding the Indian principles. Manana happens when a leader engages in thinking, discussing and reefing his understanding of the principles. Nidhidhyasana is the actual application of these principles in a live setting, fine tune based on the experiences.'

\section{The role of Purusharthas described in Bhagwad Gita and its implication in ethical leadership}

Jobn Maxwell, author of "The 21 Irrefutable Laws of Leadership" defines leadership as "influence, nothing more, nothing less". He goes on to say: "He who thinks he leads but has no-one following him, is simply taking a walk." This is a functional definition of leadership, one that basically says that a leader is someone who has followers. Leadership has been described by leadership educator Todd Duncan as "a total commitment to purpose, accompanied by the determination to carry it out." This is a characteristic definition that describes the personal qualities of a leader. Bhagavad Gita describes these fundamental universal principles - as the underlying framework of the universe that reflects the purpose of the universal architect.

Leaders who align their practices with these principles will be effective leaders. Leaders who align their goals and the goals of the organizations they steward with these principles will be authentic leaders - leaders who are empowered to create a better world. Leadership is absolutely crucial. Bhagavad Gita contains the timeless principles that will empower leaders to be effective and authentic leaders. According to Ravindra (2015), 'There are four primary leadership roles as per the Bhagavad Gita: 


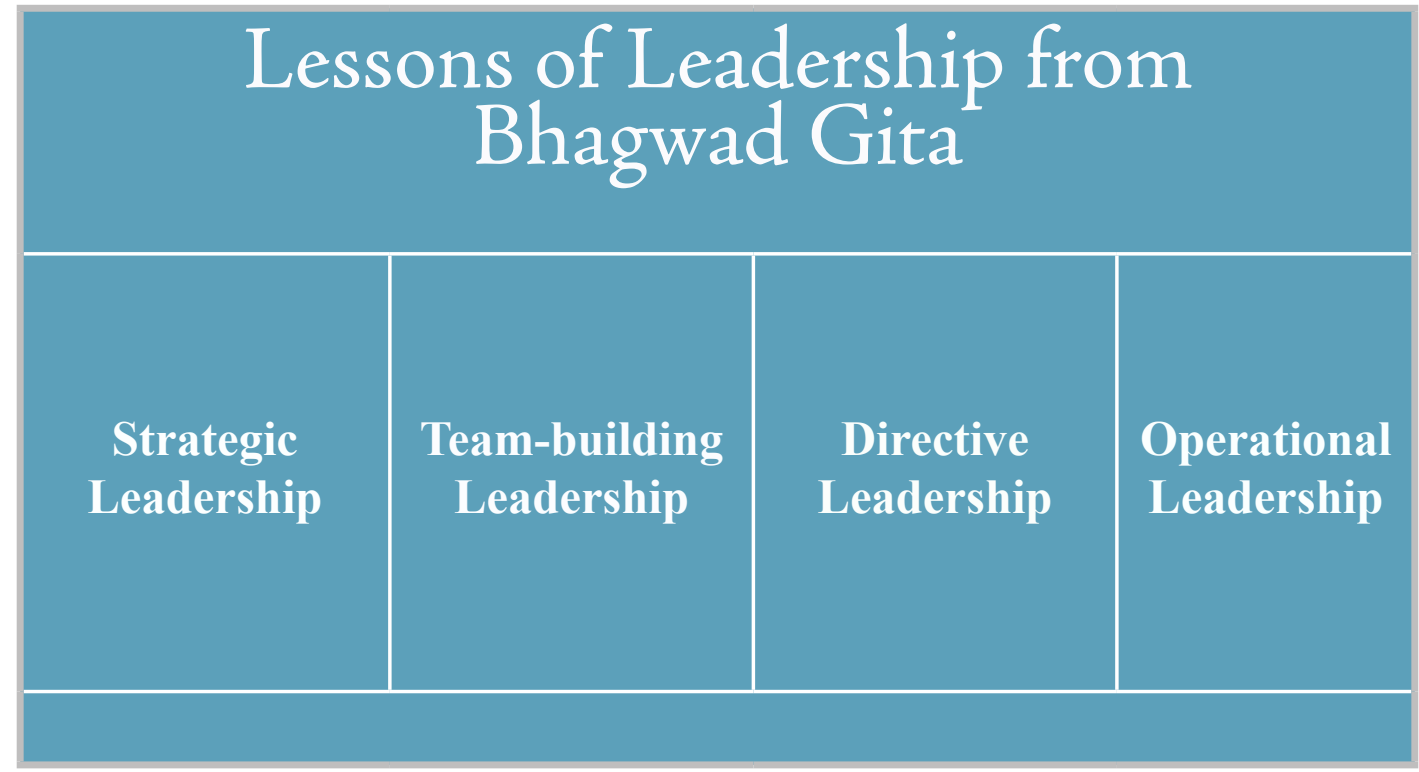

Figure1. Leadership roles according to Bhagwad Gita

2.1 Lessons of Gita for modern manager defined by Nadkarni (2016) is as follows:

1. 'When faced with a choice what is perishable or momentary and what is enduring or lasting, choose the lasting and fight for the lasting.

2. Have a higher purpose in life. Enjoy your life but don't get bogged down to momentary sensual pleasures. Don't aim at quick success through tempting. Through your work, contribute to the protection or welfare of the people, for that makes your life meaningful.

3. Consciously aim at moderation and make it a habit. Neither extreme abstinence nor indulgence is good for success; they can instead be selfdestructive.

4. Mind is fickle, tempted too easily and can divert you from your higher aims. Proper management of mind is a key teaching of Gita as it leads to success and happiness in life.

5. Manage your anger as it can cloud your reasoning, lead to confusion and can divert you from your path. Try to keep it calm, cool and composed. Steady and focused mind is great asset.

6. Be focussed on your, but take all aspects of the problem at hand. 
7. Don't lose opportunities of fighting for a good cause, if you have the aptitude of a fighter. Cowardice is worse than defeat.

8. Learn to adjust to change in circumstances even if adverse and try to innovate by adopting novel ideas, just as you discard old worn out cloths and wear new ones. Be enterprising.

9. Depend upon what is wise without being narrowly selfish. Be cautious that even knowledge or information may be at times masked by ignorance or misinformation, resulting in confusion and misleading you.

10. Nothing inferior in work. All works and their fruits are offered to God'

According to Shrivastava (2016),'No work of Indian literature has ever been revered as much as the sacred Bhagavada Gita; which not only continues to inspire Indians even today, but also remains admirable even to this day in the western countries. Over the years, these words of wisdom from within Bhagavada Gita has offered humans some respite from restlessness, complications and unhappiness; helping them sail into the light of calmness. The practical teachings mentioned in Bhagavada Gita has a message for every human; in fact, it is believed that an individual can seek answers to almost every question about Universe, his/her Past, Present and Future, in this holy book. The famous personalities of the world inspired by Bhagwad Gita are Mahatma Gandhi, Netaji Subhash Chandra Bose, Albert Einstein, Annie Besant, Hermann Hesse, Dr. Albert Schweitzer, Carl Jung, Aldous Huxley, Ralph Waldo Emerson, Rudolph Steiner, Henry David Thoreau and Sunita Williams.'

\section{Bhagwad Gita as a source of inspiration}

According to Sen (2005), 'Krishna's moral position has also been eloquently endorsed by many philosophical and literary commentators across the world, such as Christopher Isherwood and T.S.Eliot. This admiration for Gita, and for Krishna's arguments in particularly, has been a lasting phenomenon in parts of European culture. It was spectacularly praised by Wilhelmvon Humboldt as the most beautiful, perhaps the only true philosophical song existing in any known language.' We are analyzing the leadership and management skills of Indian leaders in context of Indian perspective of management. It is an attempt to enrich the management studies from eastern or Indian approach of management. Leaders such that, Mahatma Gandhi, Netaji Subhash Chandra Bose, Bal Gangadhar Tilak, Sir Aurobindo are prominent personalities of India who lived their life according to lessons of Gita. They always 
inspired, motivated and strengthen themselves through reading Gita. According to Hindu (2014), 'Many of the most prominent freedom fighters were inspired by the Bhagavad Gita. Many even went to the gallows and were executed with the Gita in their hands. The Swadeshi movement of Bengal in 1905 began with a gathering of 50,000 people on the streets on the streets of Calcutta, each with the Gita in their hands. The crowds proceeded to the Kali Temple where they vowed to boycott British goods and drive the British from their lands. We have exemplified famous Indian leader and drawing inferences of leadership and management from them.

\subsection{Mahatma Gandbi a Non-Violent leader}

"A small body of determined spirits fired by an unquenchable faith in their mission can alter the course of history." - Mabatma Gandhi

According to Rao, (n.d.), 'Mahatma Gandhi exemplifies leadership and managerial capabilities in the most myriad and trying situations. One can take various lessons in Self-Management, Leadership, Emotional Intelligence, Negotiation, Strategy, Economics, Communication, Rural Development, Social Inclusion, Education, Entrepreneurship, Women Empowerment, Law, Ethics and Corporate Governance from his work and methods. Self-management and a constant strife towards improvement was the hallmark of Mahatma Gandhi's thoughts and practices.

Mahatma Gandhi definition of Leadership - "I suppose leadership at one time meant muscles; but today it means getting along with people."

\subsection{The prominence of Bhagwad Gita in the life of Mabatma Gandbi}

'Inspirations described by Byles (n.d.) both mould and give direction to life. Sources of Inspiration could be personal and impersonal. As for personal as well as impersonal sources of Inspiration, M. Gandhi himself has said!"Three moderns have left a deep impress on my life and captivated me. Raychandbhai by his living contact; Tolstoy by his book," The Kingdom of God is within you; and Ruskin by his 'Unto This Last'. Besides these three personalities, Gopal Krishna Gokhale and the Gita and the Bible were lifelong sources of inspiration for Gandhi. Gandhi read the Gita for the first time in England, i.e. Sir Edwin Arnold's "The song Celestial", and it made a deep impression on his mind and Gandhi regarded the Gita par excellence for the knowledge of Truth and it afforded him invaluable help in his moments of gloom. The Gita became Gandhi's lifelong companion and guide, especially the last eighteen verses of the second chapter of the Gita. Gandhi derived the Gospel of selfless action 
or duty from the Gita. His commentary on the Gita reflects his life and mission. Gandhi said that "no one is competent to offer Satyagraha unless he has a living faith in God". And the Bhagavad-Gita, to which he would always turn for inspiration, is the allegorical description, not of a Satyagraha campaign, but of the quest of the human soul for union with the Supreme or God. Further, in the eyes of the Gita the outward work that Gandhi did in liberating India and raising the depressed classes, is of no more importance than the work of a humble scavenger, while Gandhi himself ceaselessly reiterated that no work is superior or inferior. It was this quest for God that determined Gandhi's every action. And let us remember that when he said Truth is God, Truth did not mean only devotion to material facts. Far more important for him was devotion to the Inner Light that the rishis of India and the authors of the Upanishads told of and experienced.

It is that all work; say both the Gita and Gandhi must be offered to the Lord, or the Supreme, as a sacrifice, something to be made holy because it is done as a service to all. When the universe was created, simultaneously the law of sacrifice, the opposite of creation, was brought into being, for the universe is composed of pairs of opposites. Gandhi says that "Sacrifice means exerting one for the benefit of others, in a word, service. Look upon all creatures as Gods." That is to say, we must sacrifice ourselves for all, giving our work freely and asking nothing in return.'The Tamil work Thirukurral, written by Thiruvalluvar has numerous couplets on the qualities of a leader like, 'A person worth to be called as a king/leader who never deviates from the path of dharma, who wipes injustice from his kingdom and whose military order is never discredited. Hence, it is imperative that the leader cultivate the right attitudes governed by the right values to be a fit role model (Chatterji 2016).' So the ideas and practices in the ancient Indian or eastern texts have quite distinct role in the western management concepts.

\section{Conclusion}

There is a great wisdom in primeval works of writings because they were written to empower the people and act as archetypes for civilization of all kinds. The code of conducts, written centuries ago contained amply source of learning for every discipline of the studies and modern theories just a new form of them. The contemporary management styles and practices developed are assimilation of ancient texts from the east. They provide insight to the leaders, managers as well as to the organizations for ethical and smooth running of the business operations and their personal life. The study of leaders who got insight through them strengthens this fact. This great, 
rich and effective writings like Bhagwad Gita inspired and always motivate modern managers and proved that our long established literature is a powerful foundation for standards of life and management.

\section{References}

Byles, Marie Beuzeville. "Gandhi Through the Eyes of the Gita." mkgandhi. n.d. http://www. mkgandhi.org/articles/Marie\%20Byles.htm (accessed July 4, 2017).

Chatterji, Madhumita, Laszlo Zsolnai. 2016. Ethical Leadership: Indian and European Spiritual Approaches. Berlin, Germany: Springer.

Devarajan, R. "The word Sutra means an aphorism - a terse statement." Thebindu. 06 May 2013. http://www.thehindu.com/books/books-reviews/an-indian-view-of-management/ article4689764.ece (accessed July 4, 2017).

Hindu History. "The Gita and the Freedom of India." Hindubistory. 25 January 2014. http:// www.hinduhistory.info/the-gita-and-the-freedom-of-india/ (accessed July 04, 2017).

Kishore, Mohit. "Selfless leadership - An Indian perspective." Thehindubusinessline. 12 July 2010. http://www.thehindubusinessline.com/todays-paper/selfless-leadership-anindian-perspective/article1015759.ece (accessed July 04, 2017).

Nadkarni, M. V. 2016. The Bhagavad-Gita for the Modern Reader: History, interpretations and philosophy. Abingdon, United Kingdom: Routledge.

Ravichandran, N."A perspective on management education in India." Financialexpress. 12 October 2009. http://www.financialexpress.com/archive/a-perspective-on-management-education-in-india/527793/ (accessed July 4, 2017).

Ravindra, NV.“Bhagavad Gita And Its Influence On Leadership.” Thehansindia. 29 April 2015. http://www.thehansindia.com/posts/index/Life-Style/2015-04-29/Bhagavad-Gitaand-its-influence-on-Leadership/147597 (accessed July 04, July).

Sen, Amartya. 2005. The Argumentative Indian. London, England: Penguin.

Shrivastava, Shruti."Legendary people from around the world who were inspired by Bhagavad Gita and they are not Indians." Speakingtree. 27 June 2016. http://www.speakingtree. in/allslides/non-indians-isnpired-by-bhagavada-gita/famous-people-inspired-bybhagavad-gita-430991 (accessed July 04, 2017). 